\title{
WHAT IS A PRISONER OF WAR FOR?
}

\author{
Professor John Hickman \\ Associate Professor of Government, Berry College
}

\begin{abstract}
This article presents a conceptual map of the purposes served by continuing custody of prisoners of war and captured non-combatants. Morally legitimate and non-controversial purposes include preventing prisoners of war from rejoining their comrades-in-arms, preventing both prisoners of war and captured non-combatants from giving material support to combatants still in the field, facilitating orderly release and repatriation at the end of hostilities, and the prosecution for war crimes. Morally illegitimate purposes include punishment, exploitation as conscript labour, recruitment or conscription as combatants, exploitation for intelligence, display as proof of victory, and ideological indoctrination. Analysis of historical cases illustrating each purpose reveal that continuing custody is often motivated by multiple purposes, both legitimate and illegitimate. What explains adoption of multiple and illegitimate purposes for continuing custody? Prisoners are available for legitimate and illegitimate purposes because neither elites nor masses within the captor state typically view prisoners as members of the moral community. ${ }^{1}$ Continuing custody does not alter the perceived status of the captured as aliens who cannot be intuitively invested with expectations of reciprocity. This suggests both ending custody as soon as legitimate purposes are served and bringing the captured within the moral community while in continuing captivity.
\end{abstract}

\section{Introduction}

Throughout human history, those captured in war have presented their captors with the basic choice between immediate execution, immediate release, or continuing custody - holding them in custody pending their release or other

\footnotetext{
1 The moral community comprises those persons to whom moral obligations are owed because moral values are shared. During wartime the moral community may extend no farther than the nation or allied nations.
} 
disposition. Despite examples of the summary execution of the captured in contemporary insurgencies, modern warfare has transferred authority over prisoners of war and captured non-combatants inexorably toward higher levels of military command and imposed the general norm that all prisoners are to be held in continuing custody (Lenz 2007; Keeley 1996:83-88). Why this has occurred is only partially explained by reference to the articulation of international humanitarian law, now embodied in the four Geneva Conventions. The general tendency of modern states to hold the captured in continuing custody predates the articulation of that treaty law (Meurant 1987:239-240). That prisoners of war should not be summarily executed was already the customary if incompletely followed norm in Western European armies before the first Geneva Convention was adopted in 1864 (Starkey 2003:93-98). However, that norm did not generally extend to the treatment of captured rebels, irregulars or "uncivilized" peoples (Rothenberg 1978:89-90).

To modern sensibilities, shaped by more than a century of humanitarian activism, the reasons why modern states choose to hold prisoners of war and captured non-combatants in continuing custody appear almost too obvious for explanation. Beyond adhering to the requirements of international treaty law, prisoners of war are held in custody to prevent them from rejoining their military units, and their removal from the battlefield or theatre of war prevents them from being harmed or from being easily liberated by their compatriots still in arms. Captured non-combatants are held in custody and removed from the battlefield or theatre of war to prevent them from being harmed or to prevent them from offering material or moral support to enemy combatants who are still in arms. Removing both prisoners of war and captured non-combatants from the immediate battlefield or the theatre of war may also be undertaken to make them more tractable and less expensive to maintain in captivity. If this exhausted the purposes of states with respect to persons captured in war then there would be little story to tell and official explanations for such decisions could be accepted without demur. Yet states had and have other purposes for choosing continuing custody.

Illegitimate purposes occupy most of the space in this conceptual map or range of possible purposes served by the continuing custody. Investigating those purposes is merited not only because those captured in war are often numerous and worthy of particular moral regard because of their vulnerability, but also because articulating the full range of purposes facilitates detection of those which are morally objectionable. Just as distinguishing the types of torture makes it difficult for torturers to deceptively claim moral legitimacy, so too distinguishing the purposes of continuing custody makes it difficult for captors to claim moral legitimacy by purporting to hold prisoners captured in war for morally justifiable purposes while 
doing so for other, transparently objectionable purposes (Lenta 2006:49). That the former can be made to serve as cover for the latter will be evident from the cases used to illustrate the purposes examined below.

This article is a work of synthesis about the range of purposes served by continuing custody. As such, it neither presents an argument for a particular interpretation of international humanitarian law nor describes the routine behaviour of states. The norms that international humanitarian law imposes on captor states with respect to continuing custody are clear, and as such are weighed in the decision-making of captor states. Whether legitimate purposes characterise continuing custody, however, cannot be known with confidence because captor states may be motivated to conceal illegitimate purposes. Likewise, whether adherence to those norms actually describes the routine behaviour of states cannot be known because captor states may be motivated to conceal violations.

Care has been taken to use neutral language in this article to avoid the perception of endorsing the causes with which the captured or their captors are associated. For the sake of simplicity, this article simply distinguishes "prisoners of war," or captured combatants, from "captured non-combatants." This is intended to avoid two sources of confusion in terminology. The first results from disputes involving determinations whether rebels, irregulars, insurgents or terrorists in specific wars are in fact "prisoners of war." The second is that in international humanitarian law, both combatants and non-combatants are deemed to be noncombatants after they have been taken into custody. The general term "captured" is also used to avoid annoying repetition.

\section{Isolating prisoners of war}

The most basic, and in principle, least controversial purpose for holding prisoners of war in continuing custody is to prevent them from rejoining their comrades-in-arms. Releasing and repatriating prisoners of war who are still capable of serving before the end of hostilities might strengthen the enemy by increasing its numbers and prolong the duration of the war. The corollary principle is that the duration of war may be shortened by accepting the surrender of combatants and treating prisoners of war humanely because it makes surrender a more attractive option for combatants (Reiter and Stam 2002:66-67).

The once common alternatives to continuing custody, such as prisoner parole and exchanges of prisoners, are now rare events in modern wars. The norm of holding prisoners of war in custody until the end of hostilities is now so universal 
that modern armies employ specialised units of military police to confine prisoners of war in military prisons and prison camps until their release and repatriation. Exceptions to the norm include the release and repatriation of wounded prisoners and high-status healthy prisoners as signals to enemy political elites of a willingness to negotiate or as a propaganda message to the enemy public.

One now little known historical example of holding prisoners of war to prevent them from rejoining their comrades-in-arms during the First World War illustrates how, even under the best of circumstances, implementing this seemingly straightforward and non-controversial purpose may go wrong. Among those caught up in the late entry of the United States in the Great War in April 1917 were 1356 German Navy officers and sailors on German Navy vessels stranded in U.S. ports since the beginning of the war in August 1914 (Glidden 1973:137-138). Prior to April 1917, these German vessels were unable to leave American ports because of the militarily superior British Navy lying in wait for them in international waters. After April 1917, German vessels were seized by the United States and their officers and sailors imprisoned at Fort McPherson, in Atlanta, Georgia. While the officers of these vessels could not be conscripted as labourers under the applicable international humanitarian law - the Hague Convention of 1899 - ordinary sailors were conscripted to work on road crews together with Georgia state prison convicts or in caning chairs for a local business. Continuing custody of prisoners of war for a legitimate purpose thus made them available for other purposes.

\section{Isolating captured non-combatants}

Isolation has also been an important purpose served by the continuing custody of captured non-combatants, who are often essential sources of material and moral support for combatants in guerrilla insurgencies. The Vietnamese political theorist Truong Chinh expressed the idea in a now universal metaphor:

The people are the eyes and ears of the army, they feed and keep our soldiers. It is they who help the army in sabotage and in battle. The people are the water and our army the fish. The people constitute an inexhaustible source of strength to the army. To increase their numbers, the troops must recruit new fighters from among the people (Chinh 1963:116-117).

Captured non-combatants may engage in propaganda work, economic sabotage, feeding and sheltering guerrilla combatants, providing intelligence, or themselves taking up arms as part-time guerrilla combatants. So important are captured non- 
combatant populations to insurgencies that one effective strategy is to take the entire captured non-combatant civilian population into custody to isolate them from combatant guerrillas. Although much more numerous, non-combatants are easier to take into custody than guerrilla combatants because they are unarmed and less mobile.

The 1899-1902 Second Boer War (also known as the Boer War, Anglo-Boer War or South African War) provides an important early example of such a strategy, and its tragically high costs. This unexpectedly protracted conflict was the last in a series waged to extend British imperial rule across southern Africa. Pretext for the war to conquer the Orange Free State and Transvaal Republic was found in the denial of parliamentary voting rights to the Uitlanders (i.e., the immigrant European miners who had moved into the two republics to work gold and diamond deposits) (Judd and Surridge 2003:33 46; Pakenham 1979:44, 50). Barely concealed behind expressions of outrage about their rights were British imperialist ambition and lobbying for annexation by the magnates who owned the mines in the two republics (Judd and Surridge 2003 46-47; Pakenham 1979:33, 37). Rather than the anticipated quick war, a British Army of 250000 was stalemated by an army of 60000 Afrikaner combatants exploiting superior mobility, camouflage and knowledge of the terrain (Judd and Surridge 2003:173-186). Frustrated by the inability to close with an elusive enemy, the British chose to physically isolate the captured non-combatant populations on which the combatants depended by interning Afrikaner and African captured non-combatants in concentration camps, a military innovation first used only a few years previously by Spanish colonial authorities in the Cuban War of Independence (Judd and Surridge 2003:187-196). The Hague Convention of 1899 provided that captured non-combatants are prisoners of war, and as such are entitled to humane treatment. Whether attributable to official inattention or to unspoken official intention - the two bureaucratic impulses often resemble one another when dealing with the powerless - 27927 Afrikaner captured non-combatants and at least 14154 African captured noncombatants died due to disease and malnutrition in the concentration camps (Warwick 1983:145). These prisoners became, in effect, hostages: their deaths and the threat of death to the survivors undermined the morale of insurgents still in the field. The lesson in this case is that the potential for harm inheres in every decision for continuing custody of any population, no matter how harmless.

\section{Release and repatriation}

Another purpose for holding prisoners of war and captured non-combatants in continuing custody is to release and repatriate them in an orderly manner at the end 
of hostilities. The Geneva Convention of 1949 requires the release and repatriation of the captured without delay at the end of active hostilities. Orderly repatriation requires enumerating the captured, determining their names, nationality and status as combatants or captured non-combatants, and guarding them in secure locations where nutrition, shelter, sanitation, and health care may be provided. Somewhat paradoxically, those captured were usually relocated during hostilities to a geographic location outside the area of battle or outside the theatre of war so that they could not be liberated by their comrades-in-arms. Chaotic release and repatriation of the captured threatens the health and safety of both the captured themselves and the captured non-combatant populations through whom they must travel on their way home. Civil order may collapse under the pressure of disorganised large-scale population movements. Violence committed against and by displaced persons at the end of wars contributes an unnecessary measure of tragedy to war.

The difficulty of achieving orderly release and repatriation is illustrated by the Korean War. The numbers of captured North Korean combatants in South Korean and American custody grew from a handful to almost 136000 between July and November 1950 (Meyers and Bradbury 1968:213-214). A year later, roughly 171000 North Korean and Chinese prisoners of war and captured non-combatants were confined in overcrowded, unsanitary prison camps on Koje-do, an island off the coast near Pusan (Stueck 1995:261-262). In negotiations to end hostilities, Truman administration officials insisted on permitting the North Koreans to elect whether to be repatriated to North Korea or to remain in South Korea, and the Chinese to elect whether to be repatriated to the People's Republic of China or the Republic of China on Taiwan (Stueck 1995:258-269). The resulting screening process to identify the choices of the captured resulted in violence that temporarily deprived the captors of effective control over the camps (Steuck 1995:271-272; Hastings 1988:309-313). Two-thirds of the North Koreans elected to be repatriated to North Korea, while an equal proportion of the Chinese elected to be repatriated to Taiwan (Meyers and Bradbury 1968:216).

The lesson from the Korean War case is that the captured possess a degree of agency and they may substitute their purposes for those of their captors. Their capacity to resist their captors is a function of numbers and organisation. Ideological indoctrination, effective military leadership and discipline, and large numbers may be sufficient to threaten the control properly exercised by captors. 


\section{Demonstrating victory}

Despite Article 13 of the Geneva Convention of 1949, which prohibits subjecting prisoners of war to "insults and public curiosity," captor states are nonetheless tempted to display prisoners of war to demonstrate success in war. For example, after defeating the French at the Battle of Dien Bien Phu in 1954, the Viet Minh forced many of the almost 7000 prisoners of war to re-enact their own surrenders in front of movie cameras (Fall 1966:433). They were then marched 500 miles north through villages where the visual evidence of Viet Minh victory ragged survivors suffering from dehydration, dysentery, malnourishment and sunburn - was unmistakable to a peasant population that had once held the French in awe (Fall 1966:432, 438). Even thought the Viet Minh still did not control the Vietnamese cities or the southern one-third of the Vietnamese countryside in the aftermath of Dien Bien Phu, evidence of their capacity to achieve military victory could be shown (Fitzgerald 1972:65). That captor states are still tempted by the opportunity to demonstrate victory by displaying prisoners of war is demonstrated by the decision of the U.S. to permit the international press to film kneeling blindfolded prisoners in orange jumpsuits after their arrival at Guantanamo Bay Naval Base in 2002.

\section{Punishment}

Article 13 of the Third Geneva Convention of 1949 also protects prisoners of war against "acts of violence and intimidation." Yet violence and threats of violence against prisoners of war occur because they may be perceived as representing what is most despised about the enemy. Unlike captured non-combatants, presumably blameless and taken into custody because they were in the wrong place at the wrong time, prisoners of war are assumed to have agreed to take up arms and are therefore perceived as more responsible for the violence and destruction of war. With individual identities typically submerged in the anonymity of large numbers of fellow prisoners of war, prisoners of war are easily identified in the public mind with the hated enemy state, and public opinion often responds favourably when such prisoners are punished or threatened. The temptation to punish the captured may emerge when states are unable to assuage public anger or fear in any other manner.

Non-combatants subjected to air attacks may experience terror, grief, humiliation at being powerless and moral indignation at the loss of life. Those feelings are easily transformed into mob violence against downed airmen. Wartime patriotism and suppression of dissenting humanitarian opinion make captured noncombatant populations especially vulnerable to official manipulation. In response to 
the area bombing of German cities during the Second World War, Minister for Propaganda and General Plenipotentiary for Total War, Josef Goebbels, published an article in the Nazi party newspaper Volkischer Beobachter on 28 March 1943 encouraging Germans to kill Allied downed airmen rather than turn them over to military custody (MacKenzie 1994:494). The tide of war was turning against Germany by that date and the proposal was intended not only to give German civilians an outlet for their anger but also to stiffen their resolve to continue supporting the war effort by implicating them indirectly in the other crimes of the state (Bramstead 1965:275-277).

\section{Prosecution}

International law permits the prosecution of prisoners of war accused of war crimes.(Geneva Convention 1949:Art 85). While the overwhelming majority of the 4,47 million Japanese prisoners of war were repatriated after the Japanese surrender, small numbers were selected for prosecution (Dower 1986:298). Between 1945 and 1951, 814 Japanese, Formosan and Korean prisoners of war were prosecuted in 295 trials, with convictions obtained in 235, under the Australian War Crimes Act, primarily for offenses against prisoners of war (Sissons 1997). The resulting detailed narratives of the atrocities committed and the convictions of the defendants served the purpose of justifying sacrifices made during the war, while the acquittals would have reinforced liberal ideological values as demonstrations that the judicial process provided a measure of justice to the accused as well as the accusers. Another, less obvious purpose served by the trials was to provide political intelligence after the end of hostilities (Maga 2001:42). Information detailing the military preparedness and battle planning of the Japanese were revealed in some of the testimony given during the trial (Maga 2001:42.)

\section{Labour conscription}

The Hague Convention of 1899 and the Geneva Convention of 1929 permit enlisted prisoners of war to be used as labourers. Massive labour shortages were experienced by modern states during the First and Second World Wars because the industrial war effort created additional demand for labour and a large proportion of the working age male population was in uniform (Spoerer and Fleischhacker 2002:169-170). Prisoners of war became attractive substitutes for domestic labourers and were consequently conscripted in large numbers by captor states. Of the approximately 1850000 French prisoners of war held in Germany as of the June 22, 1940 armistice, some 220000 were formally paroled but transformed into civilian labour contractors by administrative fiat (Gildea 2002:271-290: Fishman 
1991:237-240). Repatriation of the other French prisoners of war did not begin until mid-1942 and then only in exchange for French civilian workers who were conscripted through the Vichy State's much hated Relève programme (Gildea 2002:273). In effect, Germany conscripted civilian labourers from among its prisoners of war. Abuses such as these by captor states resulted in the inclusion of Article 7 of the Geneva Convention of 1949, which stipulated that the rights of prisoners of war cannot be renounced "in part or in their entirety".

\section{Military recruitment}

The demographic problem that constrains industrial production during war also constrains military recruitment and conscription. Too few healthy young men may be available in the national population. Although international volunteers may be recruited, their numbers are usually insufficient even when they are motivated by political ideology. That leaves the recruitment of prisoners of war and deserters, a solution likely to be perceived by military resource planners as only one step beyond the common practice of recruiting imprisoned common criminals. Recruitment of prisoners of war appears most successful during civil or internal wars when joining the enemy means transferring political allegiance to a different government and its military but does not require abandoning the national homeland. The 1946-1950 Chinese Civil War may provide the most extreme example of a military successfully filling its ranks from among prisoners of war. The People's Liberation Army (PLA) recruited heavily from the ranks of captured Kuomintang Chinese Army combatants during that titanic struggle. "Some sources estimate that, by late 1948, almost half of those serving with the regular PLA armies had at some point been fighting on the opposite side" (Westad 2003:113). There is neither an explicit right nor an explicit prohibition in international law to defect to the enemy while a prisoner of war. Accompanying such a decision, however, is the risk that the defecting prisoner of war may be tried for treason if captured by the country in whose armed forces he or she previously served.

\section{Military conscription}

At the end of the Second World War, the British government's policy was to reestablish French colonial rule in Indochina despite opposition from the Viet Minh (Marr 1995:301; Tarling 1988:37-43). However, the liberated French combatants in the colony were too few, too undisciplined or too enfeebled by their captivity to enforce French rule (Bartholomew-Feis 2006:282-291). Military commitments elsewhere and popular pressure for demobilisation meant that the British military had too few British or other Commonwealth troops for the task. Rather than 
acquiesce in Viet Minh power over southern Indochina, reliance was on the formally surrendered yet still armed units of the Japanese Imperial Army (Springhill 2005:118-127). Unsurprisingly, Japanese willingness to comply with British conscription was less than unanimous and many deserted to the Viet Minh (Marr 1995:542-543).

Although it did not violate Article 44 of the Hague Convention of 1899 and Article 23 of the Hague Convention of 1907 against being compelled to take part in military service against their own country, conscripting prisoners of war to serve as colonial militarised police officers violated Article 75 of the Geneva Convention of 1929 requiring repatriation without delay at the end of hostilities. If their provenance was extremely irregular, the Japanese prisoners of war gave the British government the means to accomplish its strategic objectives. Although their conscription was a violation of international humanitarian law, it could be rationalised as paling by comparison with the violations by the Imperial Japanese Army across East Asia and Southeast Asia. On the slippery slope, the next step downward would be to thrust captive combatants into the role of frontline soldiers.

\section{Intelligence}

Traditionally, prisoners of war and captured non-combatants have been questioned to gather military intelligence (Kaplan 1990:117). Questioning the captured is permitted under the Geneva Convention of 1929, although prisoners of war are not required to provide more than a minimum of information about their own identity (Detter 2000:327-329). Harsh interrogation is impermissible. However, prisoners of war may provide more than the minimum of information. Faced with an intractable rural insurgency, the Government of South Vietnam launched the Chieu Hoi or Open Arms programme in 1963 (Catton 2002:188, 206; Spector 1993:285-287). The programme may have been successful in encouraging as many as 85000 National Liberation Front and North Vietnamese Army prisoners of war and combatants still in the field to defect to the Government of South Vietnam (Whittaker 1997:168; Koch 1973:11). Interviews with the defectors provided political intelligence about the motivations of combatants, the importance of which may have been fully grasped only in recent guerrilla wars when ideological mobilisation became crucial to victory (Kellen 1972:99-112). The interrogators attempted to focus on discovering the factors determining whether the enemy continued to fight or defected, and in particular whether the Chieu Hoi program was effective (Goure 1968:25-31). 


\section{Indoctrination}

The Geneva Convention of 1929 fails to explicitly prohibit captor states from attempting the political and ideological indoctrination of prisoners of war, and captor states have attempted to indoctrinate them with different political, economic and social ideas. However, Article 34 and Article 38 of that treaty guarantee the captured, respectively, "complete latitude in the exercise of religious duties" and respect for the "practice of intellectual, educational ... pursuits." Ideological indoctrination potentially conflicts with such guarantees. Although it occurred two decades before the 1977 Protocol Additional to Geneva Conventions that clearly extends protection to prisoners of war in an internal war, the British colonial government of Kenya's indoctrination of prisoners in continuing custody during the colonial war in Kenya (conventionally named the Mau Mau Rebellion) provides an interesting example (Detter 2000:329).

The war erupted in late 1952 when ethnic Kikuyu, Embu and Meru who had sworn oaths in secret ceremonies, launched scattered attacks on white British settlers and African elites who collaborated with the colonial state (Elkins 2005:32-46). Before the official state of emergency ended in 1959, some 70000 Kikuyu together with smaller numbers of Embu and Meru suspected of having sworn Mau Mau oaths were interned in prison camps and some 1090 prisoners hanged (Anderson 2005:290-291). What makes the British response to the Mau Mau Rebellion interesting is the emphasis placed on ideological indoctrination. Mass internment made tens of thousands available not only for liberal political indoctrination but also for Protestant and Roman Catholic religious conversion or re-conversion. Conceiving Mau Mau oath-taking as simultaneously an anti-colonial political challenge and an anti-Christian religious challenge, instruction in some of the prison camps emphasised Christian evangelisation or re-evangelisation (Leakey 1977:4193, 127-141; Carothers 1954). What alarmed colonial authorities profoundly was that many Mau Mau oath-takers rejected Christianity for traditional religious beliefs more relevant to their experience of racial and cultural subordination under colonial rule (Peterson 2003:87-88). Thus, their answer was to demand individual confession from the prisoners as evidence of rehabilitation.

Rehabilitation was thought reform, and ... its symbol was the ubiquitous loudspeaker, found in every barrack. The loudspeakers would announce the names of those scheduled for interrogation; deliver speeches by visiting loyalist chiefs; pour out "streams of pro-Government propaganda," praising the British and the loyalists; issue sermons on the virtue of confession, the evils of Mau Mau, and the benefits of being allowed to go home". Some barracks attempted to "smother the 
box with blankets until the noise became a comical gurgle", but this only won a brief period of respite until a co-operator called a warder and the blanket was removed. The voice of Big Brother blaring into the barracks would drive some men to despair... The loudspeakers would simply wear some people down (Clough 1998:195). Brutality, isolation and unrelenting propaganda caused political solidarity to collapse in some of the internment camps, an event followed by mass confessions and conversions (Clough 1998:196-198).

Even the appearance of successful control over the content of thoughts presents a much more complete imprisonment than mere control over physical bodies, not only to the prisoners themselves but also to domestic and enemy public opinion. If successful, indoctrination facilitates the achievement of several of the other purposes for continuing custody, legitimate and illegitimate. Successfully indoctrinated prisoners of war are unlikely to rejoin their comrades-in-arms even if released, are unlikely to give material support to combatants still in the field, and may more readily offer information for intelligence and evidence for the prosecution of war crimes. To the extent that it renders the captured more tractable and trusting, indoctrination would also facilitate their exploitation as conscript labourers and their recruitment or conscription as combatants. Indoctrination could be conceived as a sophisticated form of punishment because it deprives the captured of the personal autonomy associated with human dignity. Captor states successful in indoctrinating prisoners of war may exploit them in propaganda exercises that permit prisoners of war to be displayed as a demonstration of victory. Finally, indoctrinated prisoners of war may be used to impose client regimes on conquered nations (Biess 2006:130132).

\section{Conclusion}

This article outlines the eleven basic purposes for which prisoners of war and captured non-combatants are held in continuing custody by captor states. These purposes include both the morally legitimate and illegitimate. The legitimate purposes are identifiable and serve the essential objective of international humanitarian law with respect to the captured by limiting the violence of war through precautionary measures rather than the imposition of sanctions (Detter 2000:327). Illegitimate purposes are identifiable because they permit captor states to derive utility from prisoners of war and captured non-combatants other than the advantage of reducing the total number of combatants that the enemy state may field. Adding to the complexity of identifying the captor states' purpose for continuing custody is that political and military leaderships often have multiple purposes, may change their minds about their purposes in response to perceived 
opportunities or frustration, and are more likely to dissemble about the reasons for policies during wartime than at other times. Indeed, multiple purposes for continuing custody may be the norm rather than the exception.

What explains the tendency of captors to adopt multiple and illegitimate purposes for continuing captivity? Much of the answer is expressed in the adage that "opportunity makes thieves". Captives available for legitimate purposes are also available for illegitimate purposes because neither elites nor masses within the society whose state holds them in continuing custody typically view them as part of the moral community. Continuing custody does not alter the perceived status of captives as outlanders or "barbarians" who cannot be intuitively invested with expectations of reciprocity. The fact of captivity is a powerful barrier to learning about captives and including them within the moral community.

[W]hen we know little of others, we have scant evidence to help us to decide definitely what our attitude, beliefs, and suspicions about them really are ... Because it is far easier to be self-deceived about distant, than about domestic, injustice, unjust persons persuade themselves with little psychic cost, that brutality and dishonesty are proper and prudent... (Boxill 1980:369).

Opportunity and self-deception combine to cause captors to succumb to the temptations of illegitimate purposes for continuing custody of captives taken in war. This suggests both ending custody as soon as legitimate purposes are served and bringing captives within the moral community while in continuing captivity.

\section{References}

Anderson, D. 2005. Histories of the Hanged: The Dirty War in Kenya and the End of Empire. New York: W.W. Norton.

Bartholomew-Feis, D. 2006. The OSS and Ho Chi Minh: Unexpected Allies in the War against Japan. Lawrence, KS: University of Kansas Press.

Biess, F. 2006. Homecomings: Returning POWs and the Legacies of Defeat in Postwar Germany. Princeton: Princeton University Press.

Boxill, B.B. 1980. How Injustice Pays. Philosophy and Public Affairs, 9(4):359371.

Bramstead, E.K. 1965. Goebbels and National Socialist Propaganda, 1925-1945. 
East Lansing, MI: Michigan State University Press.

Carothers, J.C. 1954. The Psychology of the Mau Mau. Nairobi: Government Printer.

Catton, P.E. 2002. Diem's Final Failure: Prelude to America's War in Vietnam. Lawrence, KS: University Press of Kansas.

Chinh, T. 1963. Primer for Revolt: The Communist Takeover in Viet-Nam. New York: Praeger.

Detter, I. 2000. The Law of War, $2^{\text {nd }}$ edition. Cambridge: Cambridge University Press.

Clough, M.C. 1998. Mau Mau Memories: History, Memory \& Politics. Boulder, CO: Lynne Reinner.

Dower, J.W. 1986. War without Mercy: Race and Power in the Pacific War. New York: Pantheon.

Elkins, C. 2005. Imperial Reckoning: The Untold Story of Britain's Gulag in Kenya. New York: Henry Holt.

Fall, B. 1966. Hell in a Very Small Place: The Seige of Dien Bien Phu. Cambridge, MA: Da Capo Press.

Fishman, S. 1991. Grand Delusion: The Unintended Consequences of Vichy France's Prisoner of War Propaganda. Journal of Contemporary History, 26(2):229254.

Fitzgerald, F. 1972, 2002 (Reprint). Fire in the Lake: The Americans and the Vietnamese in Vietnam. Boston: Back Bay Books.

Geneva Convention, Geneva Convention Relative to the Treatment of Prisoners of War. Geneva, 12 August 1949, Article $85 . \quad$ Available: http://www.icrc.org/ihl.nsf/FULL/375?OpenDocument [Retrieved July 9, 2006].

Gildea, R. 2002. Marianne in Chains: Daily Life in the Heart of France during the German Occupation. London: Picador.

Glidden, W.B. 1973. Internment Camps in America, 1917-1920. Military Affairs. 37(4):137-141. 
Goure, L. 1968. Inducements and Deterrents to Defection: Analysis of the Motives of 125 Defectors. Advanced Research Projects Agency, Rand Corporation. RM5542-1-ISA/ARPA.

Hastings, M. 1988. The Korean War. New York: Touchstone.

Judd, D. and Surridge, K. 2003. The Boer War. New York: Palgrave Macmillan.

Kaplan, R. 1990. The Hidden War: British Intelligence Operations during the American Revolution. The William and Mary Quarterly, 47(1):115-138.

Keeley, L.H. 1996. War before Civilization: The Myth of the Peaceful Savage. New York: Oxford University Press.

Kellen, K. 1972. The View from Hanoi, in J.J. Zasloff and A.E. Goodman (eds.). Indochina in Conflict. Lexington, MA: Lexington Books.

Koch, J.A. 1973. The Chieu Hoi Program in South Vietnam, 1963-1971. Advanced Research Projects Agency, Rand Corporation. R-1172-ARPA. Available: http://rand.org/pubs/reports/2006/R1172.pdf. [Retrieved May 16, 2008].

Leakey, L.S.B. 1977. Defeating Mau Mau. London: Methuen \& Co.

Lenta, P. 2006. The Purposes of Torture. South African Journal of Philosophy, 25(1):48-61.

Lenz, R. 2007. Documents Show Troops Disregarding Rules. Associated Press, September 4.

MacKenzie, S.P. 1994. The Treatment of Prisoners of War in World War II. The Journal of Modern History, 66(3):487-520.

Maga, T. 2001. 'Away from Tokyo': the Pacific Islands War Crimes Trials, 19451949. The Journal of Pacific History, 36(1):37-50.

Marr, D.G. 1995. Vietnam 1945: The Quest for Power. Berkeley: University of California Press.

Meurant, J. 1987. Inter Arma Caritas: Evolution and Nature of International Humanitarian Law. Journal of Peace Research, 24(3):237-249.

Meyers, S.M. and Bradbury, W.C. 1968. Socio-Political Behavior of Korean and 
Chinese Prisoners of War in the Korean Conflict: A Historical Analysis, in S.M. Meyers and A.D. Biderman (eds.). Mass Behavior in Battle and Captivity: The Communist Soldier in the Korean War. Chicago: The University of Chicago Press.

Pakenham, T. 1979. The Boer War. New York: Random House.

Peterson, D. 2003. Writing in Revolution: Independent Schooling \& Mau Mau in Nyeri, in E.S. Atieno and J. Lonsdale (eds.). Mau Mau and Nationhood: Arms, Authority \& Narration. Oxford: James Currey.

Reiter, D. and Stam, A.C. 2002. Democracies at War. Princeton: Princeton University Press.

Rothenberg, G.E. 1978. The Art of Warfare in the Age of Napoleon. Bloomington: Indiana University Press.

Sissons, D. 1997. Sources on Australian Investigations into Japanese War Crimes in the Pacific. Journal of the Australian War Memorial [Electronic], No. 30. Available: http://www.awm.gov.au/journal/j30/sissons.htm [Retrieved March 6, 2007].

Spector, R.H. 1993. After Tet: the Bloodiest Year in Vietnam. New York: The Free Press.

Spoerer, M. and Fleischhacker, J. 2002. Forced Laborers in Nazi Germany: Categories, Numbers and Survivors. Journal of Interdisciplinary History, 33(2):169-204.

Springhill, J. 2005. 'Kicking out the Vietminh': How Britain Allowed France to Reoccupy South Indochina, 1945-46. Journal of Contemporary History, 40(1):115130.

Starkey, A. 2003. War in the Age of Enlightenment, 1700-1789. Westport, CT: Praeger.

Stueck, W. 1995. The Korean War: An International History. Princeton: Princeton University Press.

Tarling, N. 1988. Britain, Southeast Asia and the Onset of the Cold War, 19451950. Cambridge: Cambridge University Press. 
Scientia Militaria, South African Journal of Military Studies, Vol 36, Nr 2, 2008. doi: 10.5787/36-2-50 35

Warwick, P. 1983. Black People and the South African War, 1899-1902. Cambridge: Cambridge University Press.

Westad, O.A. 2003. Decisive Encounters: The Chinese Civil War, 1946-1950. Stanford, CA: Stanford University Press.

Whittaker, J.O. 1997. Psychological Warfare in Vietnam. Political Psychology. 18(1):165-179. 